\title{
Hypothermia post-cardiopulmonary resuscitation with low inputs: an experience report
}

\author{
Hipotermia pós ressuscitação cardiopulmonar com baixos insumos: relato de experiência \\ Hipotermia post-ressuscitación cardiopulmonar con bajos insumos: relato de experiencia
}

Maria Thereza Bugalho Lazzarini'

José Carlos Bonjorno Junior' ORCID: 0000-0001-7531-8986

Márcio Pimentel Fernandes" ORCID: 0000-0001-5795-9069

Ana Lúcia Gargione Galvão de Sant'Anna"' ORCID: 0000-0002-5031-9963

Regimar Carla Machadoiv ORCID: 0000-0001-6126-7663

'Hospital Santa Casa de Misericórdia. São Carlos, São Paulo, Brazil.

"Hospital de Base, Serviço de Cirurgia Cardíaca.

São José do Rio Preto, São Paulo, Brazil.

I'Faculdade de Medicina do ABC. Santo André, São Paulo, Brazil. "Universidade Federal de São Paulo, Escola Paulista de Enfermagem. São Paulo, São Paulo, Brazil.

How to cite this article: Lazzarini MTB, Bonjorno Jr JC, Fernandes MP, Sant'Anna ALG, Machado RC. Hypothermia post-cardiopulmonary resuscitation with low inputs: an experience report.

Rev Bras Enferm. 2019;72(4):1114-8. doi: http://dx.doi.org/10.1590/0034-7167-2017-077

Corresponding Author:

Regimar Carla Machado

E-mail: regimarmachado@gmail.com

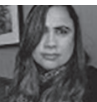

Submission: 10-31-2017 Approval: 02-27-2018

\section{ABSTRACT}

Objective: to report the experience of conducting directed temperature control of a post-cardiopulmonary resuscitation patient, with reduced and basic inputs available at the institution. Method: an experience report of directed temperature control in patient (age 15 years), after four hours of cardiopulmonary resuscitation in an Intensive Care Unit of a hospital in São Paulo State countryside in 2016, according to the protocol suggested by the American Heart Association, in 2015. There were applications of cold compresses, plastic bags with crushed ice and rectal temperature control. Results: after eight hours, temperature had reached $93.2^{\circ} \mathrm{F}$. Body cooling was maintained for 24 hours. However, bags with crushed ice were used in the first 6 hours. Conclusion: conduct of nurses to obtain the body cooling with reduced and basic inputs was effective during the stay at the Intensive Care Unit.

Descriptors: Body Temperature Regulation; Heart Arrest; Cardiopulmonary Resuscitation; Hypothermia Induced; Intensive Care Units.

\section{RESUMO}

Objetivo: relatar a experiência da condução de controle direcionado da temperatura de uma paciente pós ressuscitação cardiopulmonar, com insumos reduzidos e básicos disponíveis na instituição. Método: relato de experiência de controle direcionado da temperatura em paciente (idade 15 anos) após quatro horas de ressuscitação cardiopulmonar em uma unidade de terapia intensiva de um hospital do interior do Estado de São Paulo, no ano de 2016, conforme protocolo sugerido pela American Heart Association 2015. Utilizou-se aplicações de compressas embebidas em áqua gelada, sacos plásticos com gelo triturado e controle da temperatura retal. Resultados: em oito horas a temperatura atingiu $34^{\circ} \mathrm{C}$. O resfriamento corporal foi mantido por 24 horas, todavia os sacos com gelo triturado foram utilizados nas primeiras 6 horas. Conclusão: a conduta dos enfermeiros para obter o resfriamento corporal com insumos reduzidos e básicos, mostrou-se efetiva durante a permanência na unidade de terapia intensiva. Descritores: Regulação da Temperatura Corporal; Parada Cardíaca; Reanimação Cardiopulmonar; Hipotermia Induzida; Unidade de Terapia Intensiva.

\section{RESUMEN}

Objetivo: relatar la experiencia de la conducción de control dirigido de la temperatura de una paciente después de la resucitación cardiopulmonar, con insumos reducidos y básicos disponibles en la institución. Método: el informe de experiencia de control direccionado de la temperatura en paciente (edad 15 años), después de cuatro horas de resucitación cardiopulmonar en una Unidad de Terapia Intensiva de un hospital del interior del estado de São Paulo, en el año 2016, conforme protocolo sugerido por la American Heart Association en 2015. Se utilizaron aplicaciones de compresas embebidas en agua helada, bolsas plásticas con hielo triturado y control de la temperatura rectal. Resultados: en ocho horas, la temperatura alcanzó los $34^{\circ} \mathrm{C}$. El enfriamiento corporal se mantuvo durante 24 horas, sin embargo, las bolsas con hielo triturado se utilizaron en las primeras 6 horas. Conclusión: la conducta de los enfermeros para obtener el enfriamiento corporal con insumos reducidos y básicos, se mostró efectiva durante la permanencia en la Unidad de Terapia Intensiva.

Descriptores: Regulación de la Temperatura Corporal; Paro Cardíaco; Reanimación Cardiopulmonar; Hipotermia Inducida; Unidades de Cuidados Intensivos. 


\section{INTRODUCTION}

Cardiorespiratory arrest (CRA) can be defined as a sudden and unexpected condition of absolute tissue oxygenation deficiency due to circulatory inefficiency or cessation of respiratory activity ${ }^{(1)}$. It is emphasized that early identification and rapid response to CRA increase survival(2-3). Thus, care for CRA should be performed in a synchronized manner and based on the latest guidelines of the American Heart Association $(\mathrm{AHA})^{(2)}$ and the European Resuscitation Council (ERC) ${ }^{(3)}$.

Cardiopulmonary resuscitation (CPR) maneuvers are related to the maintenance of vital conditions through artificial ventilation and external chest compression, combined with early defibrillation, if it presents a shocking heart rhythm - ventricular fibrillation (VF) or pulseless ventricular tachycardia (PSVT), which results in a greater possibility of patient survival(2-3).

Although the care properly performed during the CRA event considerably increases the probability of better prognoses, should be added to the care after the return of the spontaneous circulation, with the purpose of preventing or treating cardiovascular dysfunctions, systemic inflammations and brain damage resulting from anoxia ${ }^{(4-5)}$. In this sense, in recent years, several techniques have been studied with the aim of improving the prognosis of the post-CRA patient. Among these, the directed temperature control (DTC) after the success of $\mathrm{CPR}^{(2-3)}$.

The DTC is included the International Liasion Committee on Resuscitation (ILCOR) recommendations, 2003 and 2010, as well as the AHA guidelines on advanced cardiology care, as being equally effective and safe $^{(2-3)}$. Such procedure is conceptualized as a controlled reduction of the central temperature of the patients with predefined therapeutic objectives according to the individual characteristics of each patient ${ }^{(2,4)}$.

Studies show that the hypothermia used for 24 hours in patients with traumatic brain injury, with stroke and under CRA caused a significant improvement of the neurological recovery ${ }^{(6-7)}$.

Currently, the main applications of hypothermia involve neurological protection after cardiopulmonary resuscitation $\left(\mathrm{CPR}\right.$ - with target temperature of $\left.89.6^{\circ} \mathrm{F} \pm 33.8^{\circ} \mathrm{F}\right)$, during highly complex cardiac or neurological surgeries, in the treatment of refractory intracranial hypertension, as well as in some conditions that evolve to a poor prognosis with increasing temperature ${ }^{(5)}$.

The update of the AHA and ERC guidelines for CPR, published in 2015 , recommends DTC, target temperature of $93.2^{\circ} \mathrm{F}$ for at least 24 hours, to all adult patients in coma with spontaneous heart rhythm (SHR) following $\mathrm{CRA}^{(2-3)}$.

Studies have shown that the DTC allows a better neurological protection, since it reduces the cerebral tissue oxygen demand, which can improve the prognosis of these patients ${ }^{(4,8-9)}$.

One study found improvement in neurological outcome in patients in whom hypothermia was induced. Therefore, the recommendation to select a target temperature and apply the DTC remains in force ${ }^{(8)}$.

Although studies and guidelines recommend DTC for post-CRA patients in coma, its use is not extensive in clinical practice. This may be due to the lack of training of professionals or the lack of institutional protocols that determine the management in the control accomplishment ${ }^{(7)}$. Thus, given the successful practice of applying basic techniques for DTC, according to the guidelines recommendations $^{(2-3)}$ in an Intensive Care Unit (ICU) of a philanthropic hospital in São Paulo State countryside, justifies this experience report.

\section{OBJECTIVE}

To report the experience of conducting a patient's post-CPR DTC with reduced and basic inputs available at the institution.

\section{METHODS}

This is an experience report in a hospital in São Paulo State countryside, in a 10-bed tertiary adult ICU that serves clinical and surgical patients. The case was conducted by ICU's multiprofessional team, consisting of a medical coordinator, a medical doctor, a physiotherapist, a nursing coordinator, a nurse practitioner and six nursing technicians per shift.

Case sampling, using the DTC technique, consists of a 15-yearold patient who presented CRA while hospitalized in ICU, in the postoperative period of emergency abdominal surgery.

The patient remained in coma after attending CPR. Four hours later, by decision of the multiprofessional team, the cooling measures were initiated to implement the DTC.

Plastic bags containing crushed ice were wrapped in thin sheets to protect the skin on the flanks, thorax, armpits and the posterior region of the legs. Cold surgical compresses were applied to the frontal and occipital regions. Compresses were changed every one hour, totaling 23 changes. However, bags with crushed ice did not need to be changed because they were used in the first 6 hours.

Rectal temperature was measured every 30 minutes by means of a mercury thermometer. In addition, an hourly inspection of the skin was performed to avoid lesions. Temperature was checked every 30 minutes because the unit did not have a continuous thermometer that would allow more adequate temperature monitoring.

When the temperature was maintained at $95^{\circ} \mathrm{F}$, the bags were removed with ice, however, the ice bags were preserved, resulting in a rectal temperature of $93.2^{\circ} \mathrm{F}$. After 24 hours, all bags were removed and rectal temperature remained at $96.8^{\circ} \mathrm{F}$.

The study followed the ethical standards for clinical research in humans according to Resolution 466/12 of the NHC (CNS) of the Ministry of Health $(\mathrm{MoH})$. The consent of the ICU of the hospital and the person responsible for the patient who signed the Free and Informed Consent Form was obtained.

\section{RESULTS}

Results are presented through a case report of the intervention strategy, using alternative techniques to reduce the central temperature of a post-CPR patient in coma.

A 15-year-old female patient admitted to a public hospital's medical center in São Paulo countryside at 7:35 p.m., on 05/31/2016, sent by the Emergency Mobile Service (SAMU - Serviço de Atendimento Móvel de Urgência), presenting abdominal pain, vomiting and fever for more than five days.

On physical examination, the patient had a Glasgow Coma Scale score of 15, as well as euphne, tachycardic, afebrile, hypocoratous, abdomen painful palpation and distended. A tomography scan of 
the abdomen was performed, which evidenced fluid in the mean quantity in the cavity and the presence of a suggestive collection image on the right flank, being submitted to emergency surgery (exploratory laparotomy), under general anesthesia, she found appendicitis with purulent peritonitis.

The surgery lasted one hour and thirty minutes without complications, but the patient presented hemodynamic instability, remaining intubated under mechanical ventilation (CVP/ RR 14 / PEE11/PET 28/FIO $28 \%$ )and under anesthetic effect, being referred to the ICU, without drains.

Patient was admitted to ICU, with the following vital signs: blood pressure (BP) of $140 \mathrm{mmHg} / 70 \mathrm{mmHg}$, heart rate (HR) of 130 beats per minute (bpm), respiratory rate (RR) of 14 breaths per minute (rpm) and rectal temperature of $100.04{ }^{\circ} \mathrm{F}$. Sedation with Fentanyl citrate at 500 micrograms per hour ( $\mathrm{mcg} / \mathrm{h}$ ), infusion pump (IP), and hydration with lactated ringer $500 \mathrm{ml}$ at $125 \mathrm{ml} / \mathrm{h}$.

Laboratory tests showed arterial blood gas at $\mathrm{pH}=7.3, \mathrm{PO}_{2}=116.7$ $\mathrm{mmHg}, \mathrm{PCO}_{2}=46 \mathrm{mmHg}, \mathrm{HCO}=22.7 \mathrm{meq} / \mathrm{L}$ and $\mathrm{Be}=3.6$. Hemoglobin hemoglobin $(\mathrm{Hb})$ of $11.1 \mathrm{~g} / 100 \mathrm{ml}$, hematocrit $(\mathrm{Ht})$ of $34 \%, 29,700$ $\mathrm{mm}^{3}$ of leukocytes, $330,000 \mu \mathrm{l}$ of platelets, lactic acid of $3.2 \mathrm{mg} / \mathrm{dL}$ and creatinine of $1.6 \mathrm{mg} / \mathrm{dL}$. Patient was under use of ciprofloxacin and metronidazole. Chest XR was also performed, which showed no abnormalities.

After three hours of ICU admission, patient presented CRA in VF rhythm, performing CPR (advanced life support), with an emphasis on the algorithm to meet the shocking rhythms of the AHA guidelines. Chest compressions/360 Joules precordial shock with monophasic cardioverter and three cycles of adrenaline were started. After 15 minutes, patient returned to the sinus rhythm with $\mathrm{HR}$ of $130 \mathrm{bpm}$, BP of $60 / 40 \mathrm{mmHg}$, being installed norepinephrine at $0.33 \mathrm{mcg} / \mathrm{kg} /$ min in IP, but with a three score of three in the Glasgow coma scale, in addition to mydriatic pupils. Thus, it was sedated with fentanyl $500 \mathrm{mcg} / \mathrm{h}$ for cerebral preservation and hypothermia.

At 7:00 a.m., due to the multidisciplinary discussion of the case, the DTC was carried out, which was started at 8:00 a.m. Cooling was carried out with cold applications with cold surgical compresses in the frontal and occipital regions, changed every one hour; crushed ice contained in a plastic bag, wrapped in a thin sheet (for protection of the skin) on the flanks, armpits, chest and back of the legs that were changed whenever necessary. Arectal temperature was measured every $30 \mathrm{~min}$, and the other vital signs, every hour.

The DTC took approximately four hours for the temperature to drop from $98.42{ }^{\circ} \mathrm{F}$ to $95.9^{\circ} \mathrm{F}$. The procedure lasted eight hours for the temperature to reach the desired value of $93.2{ }^{\circ} \mathrm{F}$, as shown in Figure 1.

It should be noted that, for the cooling process to obtain the



Figure 1 -Temperature curve expected result, a nurse and a nursing technician remained on the bedside in the first 12 hours of therapy, waiting for the patient to stabilize the temperature at the desired level.

A radial artery catheter was installed for continuous BP monitoring and to facilitate collection of blood for examinations, such as arterial blood gases, electrolytes, lactate, and blood glucose.

The following day, mechanical ventilation was maintained, sedation was discontinued, and patient presented a Glasgow Coma Scale score of 11, four for ocular opening, one for verbal response, and six for motor response. After 48 hours of cooling, patient was extubated, but with lowering of consciousness level. After two days, patient presented progressive improvement of the level of consciousness and of the infectious process that was accompanied by leukogram and magnetic resonance control. Patient was discharged from the ICU to the ward, with no neurological sequel, after 10 days of CRA.

\section{DISCUSSION}

The multiprofessional team decision to submit the patient to the DTC was based on the recent AHA and ERC guidelines (2015) ${ }^{(2-3)}$, which recommend that all adult patients in coma (with no responsiveness to verbal commands) with spontaneous circulation return (SCR) after CRA spontaneous circulation should be submitted to DTC with a target temperature of $93.2^{\circ} \mathrm{F}$ maintained constantly for at least 24 hours.

Studies ${ }^{(4,7)}$ demonstrate the benefits of using therapeutic hypothermia $(\mathrm{TH})$ in patients in coma recovered from a CRA. Some of these benefits are cerebral oxygen consumption reduction, chemical reactions suppression associated with reperfusion injury, free radical reactions reduction that increase brain damage, intracellular calcium release reduction, apoptosis modulation, modulation of anti-inflammatory response and lipoproteic membranes protection.

A randomized clinical trial of 10 ICUs from 10 university hospitals in six European countries analyzed the DTC at $91.4^{\circ} \mathrm{F}$ for 48 hours, showed better neurological results compared to the recommended 24-hour standard, noting improved neurological outcomes and reduced length of hospital stay in ICU ${ }^{(4)}$.

In this report, patient with the DTC was maintained for 24 hours, not 48 , to reduce the risk of skin lesion and the need for one or two members of the nursing staff to remain watching only the patient.

There are several forms of cooling, such as the use of ice bags, frozen infusions in the carotid artery, the use of the cover containing icy solutions (-22 $\left.{ }^{\circ} \mathrm{F}\right)$, nasal, gastric, bladder, peritoneal and pleural lavage, cooling catheters, infusion of frozen liquid, frozen air circulation blanket ${ }^{(2)}$. Above all, the ideal cooling should be one that achieves a faster and more practical target temperature without causing injury to the patient $\mathrm{t}^{(5-6)}$.

In this case, plastic bags containing crushed ice were used due to the fact that the institution did not have other supplies, corroborating a study that found the use of ice bags in most hospitals in the country, as a resource compatible with the financial reality found. However, it requires verification of body temperature in smaller time frames ${ }^{(5)}$.

Rectal temperature of the patient was monitored every 30 
minutes, reducing, on average, $32.72^{\circ} \mathrm{F}$ per hour of application. In addition, the presence of compresses in the axillary region made it impossible to verify the temperature in this region.

Hemodynamic parameters are an important point of care for patients with DTC ${ }^{(2-3)}$. Thus, a catheter was inserted in the radial artery to monitor invasive blood pressure (IBP) and collect blood for the exams. Literature ${ }^{(6,8)}$ recommends the maintenance of mean blood pressure (MBP) levels above $80 \mathrm{mmHg}$ in post-CRA patients, with the possibility of indication of volume replacement and infusion of vasopressors, in order to reach these values, noradrenaline being the vasopressor most used during to $\mathrm{TH}^{(8-9)}$.

Pulse oximetry is not an adequate parameter during hypothermia, and mechanical ventilation (MV) adjustments based on gasometric values should be performed ${ }^{(8-9)}$, which is why the blood gas analysis was performed every six hours for monitoring adequate ventilation parameters.

Continuous electrocardiographic monitoring consists of other care provided by the nurse, with emphasis on the identification of severe arrhythmias ${ }^{(7)}$, which present in the hypothermia phase, indicate the suspension of the therapy.

It should be emphasized that, in the presence of any wakeup signal from the patient, hypothermia should be immediately interrupted and spontaneous reheating is possible ${ }^{(7)}$.

Guidelines emphasize the high efficacy of hypothermia in reducing the extent of post-CRA neurological damage, but it is an underutilized treatment at ICU ${ }^{(7)}$. However, it has attenuated mortality and neurological complications in CRA patients ${ }^{(4,8)}$.

Findings from a study ${ }^{(6)}$ that evaluated patients submitted to hypothermia after recovery from spontaneous circulation after CRA showed a significantly shorter time to stay in an ICU and stay in MV, as well as better neurological outcomes in up to one year.

In spite of the cost and benefit of DTC, the implantation of successful protocols is indicated that allows the greater use of the technique, in order to spread its use with greater amplitude in the health institutions. In this sense, the importance of the health and nursing teams to understand the neuroprotective effects of hypothermia, as well as their mechanisms of action in order to provide greater patient safety and decrease of adverse events ${ }^{(9)}$.

It is up to the nurse, together with the multidisciplinary team, to evaluate each case in order to plan the therapy according to the individual needs. In the patient in question, the DTC followed the standard of duration ( 24 hours) established in the recommendations $\mathrm{s}^{(2-3)}$.

The nurse should draw up a plan of care based on scientific evidence, in order to reach the goals of $\mathrm{TH}$ and prevent potential related complications, such as cardiac arrhythmias, coagulopathies, cold burns and hyperthermia rebound, since these complications are responsible for the worsening of brain lesions and increased oxygen consumption ${ }^{(9)}$.

The multiprofessional team decided to start the DTC. However, the implementation and follow-up of the cooling and temperature control ducts were under the responsibility of the nursing team. Above all, the nurse in charge of the team is the most active professional at $\mathrm{TH}$, since he participates in all the stages, from the decision, going through the planning, implementation, evaluation and suspension of the DTC when indicated, performing reheating. In this way, it provides comprehensive, individualized and safe care.

The process of cooling and its control demanded the presence of a nurse and a technician in the first 12 hours. The calculation of the average cost of direct nursing care may subsidize the decision on the purchase of more suitable inputs for the DTC ${ }^{(10)}$.

\section{Study limitations}

As a limitation of this study, it is noteworthy that there was no analysis of inputs costs.

\section{Contributions to the fields of Nursing, Health or Public Policy}

This study corroborates with the AHA guidelines recommendations on post-CRA procedures and becomes relevant because it presents the community with the possibility of achieving good results using low-cost and evidence-based techniques.

\section{CONCLUSION}

The nurses' behavior when using DTC with basic inputs, low cost and easy reproducibility, was effective in maintaining the target temperature during ICU stay.

A proposal contemplated in the CPR guideline was implemented that optimized the treatment, demonstrating success in neurological preservation and, consequently, contributed to the patient's hospital discharge.

\section{REFERENCES}

1. KnopfholzJ, Kusma SZ, Medeiros YRC, Matsunaga CU, Loro LS, Ortiz TM, et al. Capacity of handling a heart arrest in places with a great flux of people in Curitiba. Rev Soc Bras Clin Med [Internet]. 2015 [cited 2017 Jul 20];13(2):114-8. Available from: http://files.bvs.br/ upload/S/1679-1010/2015/v13n2/a4739.pdf

2. American Heart Association. Destaques da American Heart Association 2015. Atualização das diretrizes de RCP e ACE [Internet]. 2015 [cited 2017 Sep 10]. Available from: https://eccguidelines.heart.org/wp-content/uploads/2015/10/2015-AHA-Guidelines-Highlights-Portuguese.pdf

3. Soar J, Nolan JP, Böttiger BW, Perkins GD, Lott C, Carli P, et al. European resuscitation council guidelines for resuscitation 2015 : section 3. Adult advanced life support. Resuscitation. 2015;95:100-47. doi: http://doi.org/10.1016/j.resuscitation.2015.07.016

4. Kirkegaard H, Søreide E, de Haas I, Pettilä V, Taccone FS, Arus U, et al. Targeted temperature management for 48 vs 24 hours and neurologic outcome after out-of-hospital cardiac arrest: a randomized clinical trial. JAMA. 2017;318(4):341-50. doi: http://doi.org/10.1001/ jama.2017.8978 
5. Leão RN, Ávila P, Cavaco R, Germano N, Bento L. Therapeutic hypothermia after cardiac arrest: outcome predictors. Rev Bras Ter Intensiva. 2015;27(4):322-32. doi: http://doi.org/10.5935/0103-507X.20150056

6. Storm C, Nee J, Roser M, Jörres A, Hasper D. Mild hypothermia treatment in patients resuscitated from non-shock able cardiac arrest. Emerg Med J. 2012;29(2):100-3. doi: https://doi.org/10.1136/emj.2010.105171

7. Bernard S. Hypothermia after cardiac arrest: expanding the therapeutic scope. Crit Care Med. 2009;37(7-Suppl):S227-33. doi: https://doi. org/10.1097/CCM.0b013e3181aa5d0c

8. Cronberg T, Lilja G, Horn J, Kjaergaard J, Wise MP, Pellis T, et al. TTM trial investigators. Neurologic function and health-related quality of life in patients following targeted temperature management at $33^{\circ} \mathrm{C} \mathrm{vs} 36^{\circ} \mathrm{C}$ after out-of-hospital cardiacarrest: a randomized clinical trial. JAMA Neurol. 2015;72(6):634-41. doi: http://doi.org/10.1001/jamaneurol.2015.0169

9. Araújo TR, Menegueti MG, Auxiliadora-Martins M, Castilho V, Chaves LDP, Laus AM. Financial impact of nursing professionals staff required in an intensive care unit. Rev Latino-Am Enfermagem. 2016 ;24:e2818. doi: http://doi.org/10.1590/1518-8345.1274.2818

10. Fugulin FMT, Lima AFC, Castilho V, Guimarães CP, Carvalho A, Gaidzinsk RR. Nursing staff in the internal medicine and surgical units of teaching hospitals: composition and cost. Rev Esc Enferm USP. 2015;49(Esp2):47-53. doi: http://doi.org/10.1590/S0080-623420150000800007 